\title{
Information Technology and Participatory Democracy: Some Considerations
}

\author{
Dick Flacks
}

Please read the following in light of the following biographical context: I was one of the several dozen students who met together at Port Huron, Michigan in June 1962 to found the Students for a Democratic Society and draft the Port Huron Statement. That experience marked me for life. For me, the phrase 'participatory democracy', despite its awkwardness, encapsulates what's essential for defining the good society and for criticizing established institutions and practices, and for formulating a political agenda. And my goal as a teacher for these 43 years has been to inspire students with that vision and help empower them to fulfill it as social actors. What follows is a set of reflections (not fully developed) on the prospects for democracy in a society in which members acquire and produce knowledge and culture through the new information media.

I

For the last few years I've been helping direct an online survey of the student body of the University of California, looking, among other things, at the ways they use their time as one measure of their degree of engagement in the various domains of undergraduate experience. Our most recent survey results come from the spring of 2004 , when more than 40,000 students on the eight UC campuses responded.

Among many matters covered on this survey was the question of whether and how students followed the news. That students have been increasingly unlikely to read a daily newspaper has been noticed for some years now; still, I was taken aback to find that no more than $7 \%$ of students at the University of California said they read a newspaper daily. Indeed, only about a fifth of UC students read a newspaper with any frequency at all and something like two/ thirds never or rarely do. I find these numbers startling, although I don't have any ready at hand way to compare them with the past, I assume that the newspaper habit was substantially more widespread among students in the past.

I should add that the numbers of students getting their news from TV or radio, or from newsmagazines, aren't much greater. Indeed, I estimate that $40 \%$ of University of California students are not really following the news at all. But the finding that I want to foreground here is that about $60 \%$ of students say they do use the internet at least several times a week to get the news (and nearly a third are doing this daily).

We asked those who use the Internet to list the websites they typically go to for news. The great majority listed sites that offer quick headline scanning: Yahoo, AOL, CNN and other TV network and local newspaper sites. About $15 \%$, however, indicated that they go to web places that provide more sophisticated and in-depth possibilities: BBC, NY Times, various British newspaper sites, and the like. So, most students who follow the news rely on these sorts of websites with only fitful glances at traditional news media. There is, I should point out, a small but maybe significant group, whose daily online use of sophisticated sites was associated with daily newspaper reading.

That finding illustrates the primary point I want to make here: the Internet's effects on democratic participation are fundamentally ambiguous and contradictory. We have, on the one hand, the mass abandonment of established journalistic institutions by the American student body. My so far sketchy findings about how students are using 
the web to replace newspaper and TV news tell us little about the consequences of this abandonment; my strong impression, based on surveys of and discussion with students in my classes on political sociology, is that there has been a steady erosion of basic information and awareness of the news. The great majority of students even in an upper-division class focused on the political—can't identify many of the key players, nor articulate the key issues, that now define public policy.

Yet, on the other hand, there is that much smaller group for whom the web provides ready access to information and even insight that's richer and more varied than what might be gained by daily absorption in the NY Times, NPR, and the other traditional news sources aimed at the attentive public.

But we know almost nothing about the consequences, for both individual political understanding and shared public awareness, of the abandonment of the newspaper as the primary medium for defining and following the news. There's a lot of data about how people read a newspaper and how newspapers shape publics. How does googling the news differ from reading the morning paper? What does it mean that at any moment of the day one can use Google to get news distilled from 4,500 different international news sources? Does the web's inherent capacity to provide a range of seemingly diverse sources expand or narrow the individual's focus of attention and breadth of information?

Reading a newspaper with the morning coffee, or watching network news after dinner, seems to epitomize the image of one-way, top-down, centralized, information consumption. The online news consumer appears to be more active, autonomous, and self-directed. But. I argue with my students that there are serious caveats. First, the passive reader/viewer is receiving stories that she might not, voluntarily, pay attention to. This in contrast to the likelihood that online one pursues the topics one already is interested in. The very opportunity to make one's own selection of newsworthiness (thereby weakening the power of media to define what is news) has the likely effect of reducing awareness of issues and perspectives not already one's own.

Second, the consumer of traditional newspaper and network news is participating in a widely shared, collective experience-in contrast to the ease with which the online consumer can pursue a highly individualized, idiosyncratic, and self-oriented trajectory. How can already attenuated public discourse be sustained if members each are able to create their own, very separate worlds?

The individuation offered by the Internet is one of the many things that makes being online so attractive. We feel freer online because we can make our own way through the information ocean. We feel better informed, more autonomous in our understanding, because we can instantly compare divergent news sources and find ones that are marginalized in the mainstream. We can put the NY Times up against Al Jazeera, The Guardian and Le Monde. But is there a cost to this capacity for such individual selectivity? Does our ability to focus attention on the information and perspectives of immediate interest to us lead to less awareness of the issues, ideas, and understandings of those publics who aren't on our particular wavelengths? And does such a loss threaten to harden cleavages of culture and consciousness and intensify already evident incomprehension across such cleavages?

These are questions that pertain to the strata who are attentive to public affairs. Beyond those are, of course. masses of people, including most college students today, for whom the web's potentials for consciousness expansion are largely out of reach or unused. Checking in to Yahoo occasionally is actually more than quite a few students are doing to keep up.

Many students say that they don't follow the news because they can't trust the media, justifying their disengagement as a kind of resistance. Jon Stewart's popularity-the fact that his 'fake news' is listed by numbers of students as their primary news source-is a piece of such claimed resistance. We need to know a lot more than we do about the causes and consequences of such 'willed cluelessness'. Are the students who claim to be resisting 'biased media' by tuning out asserting a refreshingly libertarian, anarchistic readiness to oppose authoritarian politics; or, are they making themselves passive sheep readying for slaughter? Or both?

\section{II}

Classic social criticism focused a great deal on potentials for mass society. Mass media were thought to facilitate and encourage the homogenization of belief and attitude by replacing face-to-face community and local knowledge with centralized one-way communication sources. Concentration of control of media by corporate monopoly or state agencies would produce political uniformity and enhance the manipulability of atomized masses.

Although media studies diluted this scenario by showing that people at the base were not so manipulable, nor 
face-to-face ties as fragile as mass society critics had assumed, massification continues to be rightly seen as a primary cause of the erosion of democratic publics and the diminution of social capital.

The Internet and other computer based technologies for acquiring and storing information and cultural expression offer many ways to sustain personal autonomy and participatory democracy:

Web access to an enormous and global range of established media allows citizens unprecedented access to diverse sources of news, information, and opinion.

The fact that much of this material is archived online allows for fact checking and social memory that undermines the capacity of central authority to control the definition of public reality.

The ease of access to web sites, and the relatively nonhierarchical inventorying of sites by independent search engines, allows any group or motivated individual to enter the 'marketplace of ideas' and have some chance to be heard.

In a short time social inventions like Internet groups, listservs, filesharing, and blogs have provided structures that seem to undermine established top-down media controls.

Web and satellite radio enormously expand the number of audio channels available, and allow each listener to select highly individualized and idiosyncratic programming

IPod and similar technologies for storing materials further enhance such individuation. With these, the audio consumer need not plug in at all to programming produced by anyone other than himself and can be immersed in a sound collage that appears to be entirely of her own choosing.

Computer technologies allow the consumer to fundamentally remake already produced material, further expanding the power of the individual to shape his own experience of cultural products and transmit this to others.

Cultural producers need not be dependent on established corporate frameworks for disseminating their work; direct distribution through file sharing, or through online self-marketing represents a readily available alternative to the 'cultural apparatus'.

If most of the population remains dependent on packaged information and entertainment distributed by the media oligopoly, the above inventory suggests that the trends are away from what we have understood to be mass society. These technological supports for autonomy are not the province of an avant-garde. They are all massmarketed; their wide availability has already eroded the foundations of the mass cultural apparatus, as theater receipts, network ratings, newspaper readership, and CD sales figures seem to suggest.

Another way to say this is that IT and its continuous proliferation provides a new material foundation for liberty - that is, for individuals to experience the world according to their own personal preferences, and therefore to be relatively free from many of the controls historically available to dominant organizations and elites.

Walk around campus on any given afternoon and you can get a snapshot of how this plays out in mundane behavior: every third person is interacting with a cell phone; those who aren't are typically wearing headsets as they stroll, bike, and skateboard. It's at a moment like this, that I at least have Luddite thoughts (feeling a certain resentment that these folks are somewhere other than here, feeling a vague anxiety that taken for granted reality is somehow dissolving).

These feelings, I think, stem from fear that a great deal of what we have assumed to be social connectedness is dissolving. The cultural choice and autonomy made possible by new technology means that those using it need not experience themselves as members of a collectivity that is hearing the same news, or seeing the same shows, or sharing the same objects of attention. Yet, if these simultaneous and shared cultural experiences constitute much of the common coin of sociability and serve as foundations for collective identity and perception, then the new liberties I'm referring to are jeopardizing much of social fabric that enables collective action and destroying the bases for whatever is left of publics. Or perhaps new social fabric is being woven ...

\section{III}

One day in September 2002, I received an email signed by a couple of friends in town declaring that the buildup to a war in Iraq was obvious and so we ought to start protesting that. They proposed that those interested gather across the street from the Saturday Farmers' Market at 11 A.M. and march down Santa Barbara's main street with whatever signs anyone cared to bring. On that Saturday about 100 people showed up, and marched and somehow understood that we would be coming back each week, same time, same place. The numbers doubled and tripled and 
a couple of months later there were at least 10,000 on the march. Some of that happened by word of mouth, but most of the mobilization seemed to have been carried by emails, sent and resent by those already involved. Out of these, a small number took some special responsibility to get police permits when needed and eventually to organize occasional rallies with PA equipment and guest speakers and singers and the like. A group of veterans of past wars formed a Vets for Peace, spinning off a number of other creative forms of protest. A group of women spun off a 'women in white' vigil. On one occasion an email was disseminated asking that those marchers who wanted to head toward the headquarters of congresswoman Lois Capps do so on next Saturday (which hundreds did). And so, for six months or more (until shock and awe fell on Baghdad) tens of thousands of people in Santa Barbara turned out to march on Saturday, and many of these got actively involved in a range of other protest oriented antiwar activities. These happenings were very effective locally: Congresswoman Capps voted against the war; the conservative newspaper praised her and editorialized frequently against the war; the city council passed an antiwar resolution.

All of the above was almost entirely mobilized through email communication rather than by planned organizing efforts of established organizations or organizers. Santa Barbara, we learn from this experience, is rather richly endowed with social capital—numerous and diverse networks (mostly NOT based on political affiliation) could be instantly activated by online communiqués; each week's assembly amounted to a coming together of many circles of affiliation and circuits of shared interest. Showing up on Saturday was 'voluntary' (that is, not a response to structured expectations); the assertions of necessary leadership fulfilled anarchist visions about the potential for semi-spontaneous organization; small groups of participants creatively expanded protest repertoires. In this instance (repeated I am sure in hundreds of places across the planet), the Internet became a remarkable tool for collective action, for social capitalization, for new social formation.

I suggested earlier that the new technology endangers collective action, but the same technology makes for new possibilities for grassroots democracy as the above story illustrates. Here are some of the ways this is happening:

The astonishing network structures that constitute what Brecher, et al call 'globalization from below' have been made possible by the Internet. It's the web that enables the mass mobilizations on the Seattle model to come together and at the same time to allow for ramifying advocacy networks made up of local activists, NGO's, academically based researchers, and so forth to formulate policy perspectives and strategies. I take it that the World Social Forums could not happen on their current scale were it not for web-based processes of communication and online modes of registration. The Internet is the material foundation for twenty-first century corporate globalization-and for the resistance to it.

MoveOn.org is to me a rather astonishing instance of a new kind of mobilized political organization. Although its structure is 'top-down' in that a small band of full-time leaders decide what and how to target and creates the language and the framing for these, each 'member' is completely free to act or not in response to the proposals emanating from the 'top'. So in a sense MoveOn is a kind of action clearinghouse, providing a regular menu of opportunities for people to participate in a constantly unfolding series of campaigns. But there is more participation being facilitated than just signing a petition or sending some money: hundreds of thousands 'voted' before the Democratic primaries in MoveOn's own election, and thereby created Howard Dean. Thousands made and submitted campaign commercials, and hundreds of thousands judged and selected which ones to actually use. MoveOn has convened hundreds of house parties, no doubt helping to foster a number of new face-to-face encounters of the like-minded in many American towns. And it has enabled the dissemination of important video documentaries, financed a variety of political campaigns, placed potent newspaper ads and encouraged much writing of letters to politicians and newspapers.

MoveOn has demonstrated that email and web can foster not only on-line action, but that it can get people into old-fashioned face-to-face gatherings. This potential was pushed further by the Dean campaigns use of 'meetup' websites to create an astonishing network of grassroots Dean campaign operations. Deaniacs may have included some veteran liberal activists, but for the most part participants in the meetups were new to politics or had been politically passive for a long time. Dean flamed-out before the campaign potential of this mobilization was fully tested, but quite a few of the local Dean groups continued to function after the campaign and have become new centers of grassroots political action.

Deaniacs are part of the emerging grassroots base of the Democratic Party. What the roots share in the way of program, vision or expectation isn't clear, but they are certainly being watered by the dozens of blogs emerging from and aimed at them. It's the web that has been fostering the potential for the democratization of the Democratic Party. 
Like so much of web-based social action I'm enumerating, this formation is decentered, fluid, and voluntaristic.

These examples are but a sampling of the social movement/collective action potentialities now being fostered through web based means. These potentialities are reasons to hope for a future for participatory democracy.

\section{IV}

Let's go back to the student scene we started with. If the students I've been surveying or teaching are any guide, only a small number are now connected to the democratic possibilities of IT. Many more are, of course, prime consumers of its libertarian potentialities. But one may wonder how much effective use they make of those resources. Our survey data suggest that about 5\% of University of California students currently use 'alternative' websites for getting the news (I mean places like indymedia, Alternet, Buzzflash, and the like). Almost none referred to any blogs. The individuation provided by downloading is offset by the persistence of youth subcultural identities structured by commodified musical genres of which hip-hop and 'hardcore' are the primary campus nodes. My perhaps limited observation is that some kids do go deeply into these, but few deliberately try to break out of them to explore cultural expression from other places and times. Many students acknowledge they live within 'bubbles' which feel safe and which provide identity. Strikingly unlike their counterparts of the 1960s and 1970s, upper-middle-class students these days would rather be comfortable than challenged. The new technology fosters such a stance, even if it offers access to alternatives.

Whatever the reasons for this difference in student generations (and an effort to figure these out seems essential), I do think that the post-9/11 student body (the first members of which have just graduated) may well be the most politically oblivious we've seen in several decades. I know there's evidence of political engagement among today's youth. Conservative kids have never been so organized-no doubt in part because of resources made available by new technology. Progressive activism is certainly evident, and the youth vote was historically, relatively high in 2004. That vote was more 'blue' than other age groups, and this reflected a generational consensus opposed to right-wing cultural traditionalism.

Nevertheless, political disaffiliation and willed cluelessness seem to me to characterize the dominant campus mood. That mood is fostered, I think, by the way that new technologies enable the relatively affluent to construct and maintain their cultural bubbles. There are, I want to stress, thousands of University of California students whose life experience is quite different. More than half of UC students have parents who emigrated to the United States (and sizable number of students are themselves immigrants). At least a third of UC students come from low income, or working-class backgrounds. Its these ranks that provide much of today's campus leadership, community service, and political activism.

It's the relatively rich kids (who are likely to be the most technologically plugged in) who worry me. After all, it was that class of young people who fueled the new left and counterculture of the sixties. Their relative cluelessness today is not easy to explain. We need to foster a conversation about how to create pedagogy that can help students break out of their bubbles and become serious, social actors. The democratic potentials of new technology can be a resource for such a project. 
